\title{
Trace Elements In The Detoxifying And Accumulating Body Parts of Mytilus Galloprovincialis Lamark, 1819 (Crimea, Black Sea): Human Health Risks And Effect of The Sampling Site Location
}

Natalya S. Chelyadina ( $\sim$ chelydina2007@mail.ru )

A.O. Kovalevsky Institute of Biology of the Southern Seas https://orcid.org/0000-0003-2552-4073

Sergey V. Kapranov

A.O. Kovalevsky Institute of Biology of the Southern Seas

Mark A. Popov

A.O. Kovalevsky Institute of Biology of the Southern Seas

Lyudmila L. Smirnova

Institute of Natural and Technical Systems, Russian Academy of Sciences

Nikolay I. Bobko

A.O. Kovalevsky Institute of Biology of the Southern Seas

\section{Research Article}

Keywords: Mussels, Trace elements, ICP-MS, Bioaccumulation, Soft tissues, Shell liquor, Byssus

Posted Date: November 30th, 2021

DOI: https://doi.org/10.21203/rs.3.rs-1067957/v1

License: (c) (1) This work is licensed under a Creative Commons Attribution 4.0 International License. Read Full License 


\section{Abstract}

The mussel M. galloprovincialis is one of the most popular species in world's mariculture and environment pollution bioindicators. Although this mollusk was in a focus of numerous publications, the detoxifying and accumulating role of some of its body parts was insufficiently studied. In the present work, using inductively coupled plasma mass spectrometry, the distribution of $\mathrm{Cr}, \mathrm{Co}, \mathrm{Ni}, \mathrm{Cu}, \mathrm{Zn}, \mathrm{As}, \mathrm{Cd}, \mathrm{Hg}, \mathrm{Pb}$ in soft tissues, byssus, and shell liquor of this bivalve was studied for the first time as a function of sampling location in the Black Sea off southwestern Crimea. Multivariate analysis showed significant differences in the overall distribution of the elements among the body parts and sampling sites under consideration. Human health risks from the consumption of this mollusk were shown to be unlikely. Byssus of $\mathrm{M}$. galloprovincialis was characterized as an ideal indicator of marine environment pollution with $\mathrm{Ni}$, Cu, $\mathrm{Pb}$, Co, and $\mathrm{Cr}$ as it contained the highest contents of these elements among the body parts under study ( $\mathrm{Ni}$ up to $91 \%$, Cu and $\mathrm{Pb}$ up to $79 \%$ ). For the first time, the concentrations of trace elements were determined in the shell liquor and its role as the trace element excretion system was demonstrated. In the shell liquor, the largest share among the body parts was that of $\mathrm{Hg}$ (up to 71\%). In soft tissues, $\mathrm{Zn}, \mathrm{Cd}$ and As were in largest proportions among the body parts (63, 62 , and $54 \%$, respectively). The trace element contents in soft tissues of $M$. galloprovincialis decreased in the following order: $\mathrm{Zn}>\mathrm{Cu}>\mathrm{As}>\mathrm{Ni}>\mathrm{Pb}>\mathrm{Cd}>\mathrm{Cr}>\mathrm{Co}$ $>\mathrm{Hg}$.

\section{Introduction}

The Mediterranean mussel M. galloprovincialis is an important source of animal protein with high nutritional value and one of the most popular target species in bivalve mariculture. This mollusk thrives in the coastal waters of the Mediterranean and Black Seas as well as the Atlantic of the Northern Hemisphere. It is also cultivated in countries of the southern Mediterranean, in South Africa and China (Atasaral et al. 2015; FAO 2020; Gosling 2003; Kholodov et al. 2017; Lutz et al. 1991). In the Black Sea, M. galloprovincialis is extensively cultured and is one of the dominant mollusk species (Ivanov et al. 1989; Kholodov et al. 2017; Massa et al. 2017).

M. galloprovincialis is also widely used as environmental biomonitor. Substantial progress in this application has been achieved through the implementation of the "Mussel Watch" program (Cantillo, 1998; Rainbow and Phillips 1993; Stankovic and Jovic 2012). Mollusks are bioindicators of trace element pollution of environment (Casas et al. 2008; Gupta et al, 2011; Stankovic and Jovic 2012) because of their ability to accumulate trace elements in body parts to levels several orders of magnitude higher than in the surrounding water (Adams and Rowland 2003; Casas et al. 2008; Rainbow and Phillips 1993; Stankovic and Jovic 2012). Trace element contents in marine organisms depend on environmental factors, such as the trace element concentrations in seawater, temperature, salinity, dissolved oxygen concentration, $\mathrm{pH}$ value, and also on biological characteristics, such as aquatic species identity, sex and sexual ripening stage, type of tissue, organ, diet, etc. (Boening 1999; Sunlu 2006).

Many trace elements, including heavy metals, are biologically active and capable of disrupting human metabolic processes. Estimation of heavy metal contents in edible aquatic mollusk tissues is important for the assessment of human health risks from the mollusk consumption (Gupta et al. 2011). The most hazardous for human health are cadmium, copper, arsenic, nickel, mercury, lead, zinc, chromium, and cobalt (Briffa 2020; Gupta et al. 2011; Stankovic and Jovic 2012).

There exist a number of publications on the trace element levels in soft tissues and byssus of mytilids (Nicholson and Szefer, 2003; Szefer et al. 1999; Szefer et al.2002; Yap et al. 2003a; Yap et al. 2003b). Mussel byssus is known to be a better bioindicator of coastal pollution with heavy metals as compared to other tissues (Szefer et al. 1999; Szefer et al. 2002). In M. galloprovincialis shell liquor, trace element levels were studied very poorly, and to our knowledge, there is only one publication on the content of $\mathrm{Zn}$ and $\mathrm{Cu}$ in this fluid (Chelyadina and Smirnova, 2018). At the same time, the need for the study of the mussel shell liquor element composition is quite obvious as shell liquor is an important mediator in the metabolism that occurs between tissue cells and the open circulatory system of the mussel and affects the liquor composition (Chelyadina et al. 2015).

The goals of this work are: to study the distribution of the above-mentioned hazardous elements (Cd, $\mathrm{Cu}, \mathrm{As}, \mathrm{Ni}, \mathrm{Hg}, \mathrm{Pb}, \mathrm{Zn}, \mathrm{Cr}, \mathrm{Co}$ ) in soft tissues, byssus, and shell liquor of the mussel M. galloprovincialis and its dependence on the sampling location in coastal waters of the southwestern Crimea (Black Sea); to reappraise the role of byssus as a bioindicator of water pollution with the trace elements under study; to assess the role of the shell liquor as the heavy metal detoxification medium; and to assess human health risks from the consumption of the cultivated mussel meat.

\section{Material And Methods 2.1 Object of research}

The object of this study is the bivalve M. galloprovincialis with the shell sizes of $54.01 \pm 2.9 \mathrm{~mm}$. The mussel M. galloprovincialis is a common species in the Black Sea shelf zone and in the fouling of various hydraulic structures. The animals form independent biocenoses and are part of other communities. $M$. galloprovincialis has a significant potential for acclimatization, which allows them to adapt to different living conditions and occur in nearly all biotopes of the region. At present, this species has spread throughout temperate shelf waters of almost all oceans. It can exist in wide ranges of salinity $\left(8-40 \mathrm{~g} \cdot \mathrm{L}^{-1}\right)$ and water temperature $\left(1-28^{\circ} \mathrm{C}\right.$ ). The optimum temperature is $12-20^{\circ} \mathrm{C}$ and salinity $12-25 \mathrm{~g} \cdot \mathrm{L}^{-1}$ (Ivanov et.al. 1989; Kapranov et.al. 2021b). The mussel $\mathrm{M}$. galloprovincialis, being an active filter feeder, filters water at a rate of 0.5 to $7.5 \mathrm{~L} \cdot \mathrm{h}^{-1}$ and more and, as a result, accumulates trace elements from the incoming water and food, phytoplankton and detritus (Coombs and Keller, 1981; Temerdashev et.al. 2017). Soft tissues of mussels accumulate trace elements and partly remove them into shell liquor, which is involved in the metabolism between tissue cells and circulating blood (hemolymph). Shell liquor, byssus, feces, pseudo-feces and mussel gametes during the spawning make up the mollusk's excretion system (Chelyadina et al. 2015; Kapranov et.al. 2021; Pospelova 2008). 
M. galloprovincialis is a sedentary organism that, after the larval stage, settles and attaches to the substratum (rock, sediments, rope collectors, etc.) with byssal threads, which are secreted from a byssal gland in the mussel foot and provide tight attachment. Byssal threads consist of collagen fibrils incorporated into matrix protein core. Byssus plays not only the role of an attachment organ, but also performs the function of extracting heavy metals from the mussel body (Nicholson and Szefer, 2003; Suhre et al. 2014; Szefer et al. 2006).

\subsection{Characteristics of the sampling sites}

In this study, mussels were sampled in June 2017, and the temperature of the seawater environment was measured at the sampling time using a meteorological thermometer TM-10 (Termopribor, Klin, Russia).

The sampling sites were selected so as to encompass environments with different physicochemical properties and different expected levels of trace element

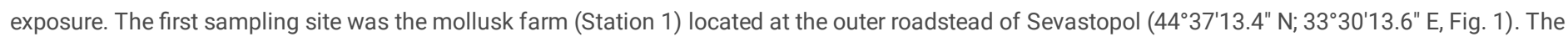
animals at Station 1 were harvested from rope collectors at a depth of $2-3 \mathrm{~m}$, where the water temperature was $21.4^{\circ} \mathrm{C}$. The second sampling site was the seafloor under the farm (Station 2). The depth at Station 2 was $16 \mathrm{~m}$ and the water temperature at the seafloor was $11.0^{\circ} \mathrm{C}$. The third place for the mussel sampling ( $44^{\circ} 36^{\prime} 41.1^{\prime \prime} \mathrm{N} ; 37^{\circ} 33^{\prime} 0.3^{\prime \prime} \mathrm{E}$, Fig. 1) was the innermost part of Sevastopol Bay (Station 3). The animals at this station were collected from the quay wall at a depth of $2-3 \mathrm{~m}$ at the water temperature of $21.8^{\circ} \mathrm{C}$.

The water in the mollusk farm area (Station 1) is ranked as mesotrophic; the trophic index (TRIX) value was 2.73. Hidden upwellings are typical for this area. The farm has sufficient water exchange and nutrient supply due to local currents even in the small wind-wave mixing regime (Kuftarkova et al. 2006). Food resources in this marine farm are favorable for the growth and development of mollusks as microalgae included in the diet of the cultivated mussels are permanently present in the phytoplankton (Ryabushko et al. 2017). The seasonal variation of salinity in the surface water is weak. The amplitude of the seasonal fluctuations of the long-term mean values did not exceed $0.4 \%$ over the last two decades, and interannual salinity fluctuations in any season were below $1 \%$, being in the range of $17.26-18.39 \%$. The $\mathrm{pH}$ values in the surface water on the farm varied in the range of $8.14-8.88$, with the median being 8.35 (Kapranov et al. 2021b; Kuftarkova et al. 2006).

The seabed under the farm (Station 2) consists of highly silted sand with rare boulders. The salinity in the farm water gradually increases from the surface to the bottom. The median difference between the bottom and surface salinities is $0.1 \%$, and the median difference between the respective pH values is nearly 0 .

The innermost part of Sevastopol Bay (Station 3) is a typical estuary, with the Chernaya River, a major source of heavy metals (Gruzinov et al. 2019), flowing into this area. Close to this sampling site, there are a shipbreaking plant and a city power plant, which are the additional sources of heavy metal pollution. In the inner part of the bay, the salinity of the upper layer varied in the range from 11.16 to $17.74 \%$ o. This area is characterized by an increase in the water salinity from the surface to the bottom and seawards, with a pronounced wedge of salt water penetrating relatively far upstream from the river mouth. The $\mathrm{pH}$ value at the sampling site was 8.42 (Boltachev et al. 2010), and the mean TRIX value in Sevastopol Bay was 4.01 (Slepchuk et al. 2017), which corresponds to the moderate trophic level.

\subsection{Analytical sample preparation}

The mussel shells were cleaned of epifauna, algae and mineral residue with a knife and wire brush and washed with seawater. Then, each mussel was dissected by cutting the adductor muscle using a plastic scalpel to isolate individual body parts (soft tissues, byssus, and shell liquor), which were further analyzed as separate samples. From the open shell, after cutting the mantle in the anterior part, the turbid shell liquor was poured in dry test tubes pre-cleaned with nitric acid and deionized water, and then, byssus and soft tissues were excised with the scalpel. The weight of the shell liquor in the mussels under study was up to $30 \%$ of their total weight. The soft tissues and byssus were blotted with filter paper and weighed. The dry weight of the soft tissues was determined after oven drying at $105^{\circ} \mathrm{C}$. Weights of all body parts were measured on an analytical balance AXIS ANG200C (Gdańsk, Poland). Byssus and tissue samples were placed in digestion tubes made of PTFE using a plastic spatula. For the digestion, concentrated nitric acid of analytic grade was additionally purified by sub-boiling distillation in an acid purification system DST-1000 (Savillex, USA) and added into the digestion tubes in a proportion of $4 \mathrm{~mL}$ per $100 \mathrm{mg}$ sample. The PTFE-capped digestion tubes with the samples and nitric acid aliquots were kept in an autoclave at $120^{\circ} \mathrm{C}$ for around 1.5 hours. Deionized water was used to dilute the digested samples to about $1000 \mathrm{~mL} \cdot \mathrm{g}^{-1}$ dry weight (d.w.).

\subsection{Trace element analysis}

The concentrations of trace elements $(\mathrm{Cr}, \mathrm{Co}, \mathrm{Ni}, \mathrm{Cu}, \mathrm{Zn}, \mathrm{As}, \mathrm{Cd}, \mathrm{Hg}, \mathrm{Pb})$ in the diluted samples were measured using inductively coupled plasma mass spectrometry (ICP-MS) on an instrument PlasmaQuant ${ }^{\circledR}$ MS Elite (Analytik Jena, Germany). The plasma flow was $9.0 \mathrm{~L} \cdot \mathrm{min}^{-1}$, the sampling depth was $8 \mathrm{~mm}$, and the RF power was $1.25 \mathrm{~kW}$. The dwell time for each element was $10 \mathrm{~ms}$, one point per peak in the peak-hopping mode. To make sure there are no significant polyatomic interferences, the measurements were carried out with the collision reaction interface (CRI) switched off and on. In the CRI mode on, gaseous hydrogen with the flow rate $40 \mathrm{~mL} \cdot \mathrm{min}^{-1}$ was used as the skimmer gas. No internal standard was used since the undesirable matrix effects were not expected due to the high dilution of the samples. The signal drift was taken into account by measuring the element concentrations in the diluted standard IVICPMS-71A after each fifth sample and using an interpolating polynomial relationship to correct the apparent concentrations in time (Kapranov et al. 2021a).

The calibration curves were obtained using a multielement standard IV-ICPMS-71A (Inorganic Ventures, USA) and a standard solution of mercury (II) nitrate (Supelco, USA) diluted with deionized water. The $\mathrm{R}^{2}$ coefficients for all linear calibration fits were greater than 0.999 . The detection limits in this analysis range from $0.03(\mathrm{~Pb})$ to $10(\mathrm{Ni}) \mathrm{ng} \cdot \mathrm{L}^{-1}$ (Chemnitzer 2019). The accuracy and precision of the ICP-MS analysis was verified by the measurement of the element concentrations in the certified European Reference Material ERM®-CE278k (tissue of the mussel Mytilus edulis Linnaeus, 1758). Samples of the reference 
material $(0.1 \mathrm{~g})$ were digested in the extra pure nitric acid and diluted with deionized water as described above. The certified and observed values are given in Table S1 (Supplementary Material).

The seawater sampling was performed in three replications at the mussel sampling sites. The seawater was filtered through a membrane filter with $0.45 \mu \mathrm{m}$ pore size (Sartorius) and acidified with the extra pure nitric acid in a proportion of $0.1 \mathrm{~mL}$ per $100 \mathrm{~mL}$ seawater. For the ICP-MS analysis, the samples were diluted 10-fold, and the dwell time was increased to $1 \mathrm{~s}$.

\subsection{Statistical analysis}

All results are presented as mean $\pm 95 \%$ confidence interval. Statistical comparisons were performed using two-way permutational multivariate analysis of variance (PERMANOVA) and permutational multivariate analysis of dispersion homogeneity (PERMDISP). The effects of the group factors (body part type and sampling location) on the overall accumulation of trace elements were analyzed and visualized by means of principal coordinate analysis (PCO) with the Euclidean distance as the similarity measure. All statistical procedures were realized in PRIMER 6.1.16 \& PERMANOVA+ 1.0.6 (Clarke et al. 2014). The differences were considered significant at $\mathrm{P}<0.05$.

\subsection{Human health risk assessment}

It is common to assess the human health risk from the estimated daily intake of a pollutant, i.e. the rate of daily consumption of the pollutant per body weight unit (Zhelyazkov et al. 2018):

$$
\mathrm{EDI}=\mathrm{CR} \times C / \mathrm{BW}_{\mathrm{a}}
$$

1

where $\mathrm{CR}$ is the food consumption rate, i. e. the average weight of daily consumed food (in $\mathrm{kg}^{\cdot} \mathrm{day}^{-1} \cdot \mathrm{capita}^{-1}$ ), $C$ is the pollutant content in the food (in $\left.\mathrm{mg} \cdot \mathrm{kg}^{-1}\right)$, and $\mathrm{BW}_{\mathrm{a}}$ is the average human body weight, which is typically assumed to be $70 \mathrm{~kg}$.

The calculated EDI values are compared with the reference data: provisional tolerable daily intake (PTDI) established by FAO/WHO (Bat and Öztekin, 2016; FAO/WHO 2011; Filippini et al. 2020), tolerable upper daily intake (UDI) set by European Food Safety Authority (EFSA 2006; Filippini et al. 2020), or oral reference dose $\left(\mathrm{RfD}_{0}\right)$ introduced by the United States Environmental Protection Agency (USEPA 2020).

Target hazard quotient (THQ) set by USEPA is the ratio of the estimated daily intake of the pollutant to its upper oral reference dose:

$$
\mathrm{THQ}=\mathrm{EDI} / \mathrm{RfD}_{\mathrm{o}}
$$

2

If $\mathrm{THQ}<1$, there are no likely toxic risks for a consumer in the long-term dietary exposure.

To assess the overall noncarcinogenic risks from the consumption of multiple contaminants, hazard index (HI) is used, which is the sum of the THQ values for each contaminant (USEPA 1989):

$$
\mathrm{HI}=\sum_{i} \mathrm{THQ}_{i}
$$

3

The values of $\mathrm{Hl}<1$ indicate no likely toxic risks to human health from the prolonged consumption of contaminated food.

\section{Results}

\subsection{Trace element contents in M. galloprovincialis and seawater}

Table 1 shows the trace element contents in soft tissues, byssus, and shell liquor of $M$. galloprovincialis sampled at the three stations as well as the concentrations in seawater from Stations 1 and 3. The highest concentrations (above $10 \mu \mathrm{g} \cdot \mathrm{L}^{-1}$ ) at Station 1 are registered for As, Zn, and Cu and at Station 3 for $\mathrm{Zn}, \mathrm{As}, \mathrm{Cu}, \mathrm{Ni}, \mathrm{Cd}$, and $\mathrm{Cr}$. There are differences in the trace element contents in soft tissues, byssus, and shell liquor that are associated with the overall mean levels of each element at the sampling sites. In all samples, the zinc content is highest. The trace element contents in the animals from different biotopes decrease in the following order: Station $2>$ Station $3>$ Station 1.

The largest shares of the trace element contents in soft tissues among the three body parts are observed for Zn, As, and Cd (Fig. 2), which suggest that these elements are most tightly bound to organic components of soft tissues. The contents of many elements under consideration are highest in byssus. The greatest shares of the trace element contents in mussel byssus are found for $\mathrm{Ni}(81-90 \%), \mathrm{Cu}(61-79 \%), \mathrm{Pb}(57-79 \%)$, and Co (54-69\%). The shares of the trace element contents in byssus among the three body parts (Fig. 2) decrease as follows:

(Station 1) $\mathrm{Ni}>\mathrm{Cu}>\mathrm{Co}>\mathrm{Pb}>\mathrm{Cr}>\mathrm{Cd}>\mathrm{As}>\mathrm{Zn}>\mathrm{Hg}$;

(Station 2) $\mathrm{Ni}>\mathrm{Cu}>\mathrm{Co}>\mathrm{Pb}>\mathrm{Cr}>\mathrm{Cd}>\mathrm{As}>\mathrm{Zn}>\mathrm{Hg}$;

(Station 3$) \mathrm{Ni}>\mathrm{Pb}>\mathrm{Cu}>\mathrm{Cr}>\mathrm{Co}>\mathrm{Zn}>\mathrm{As}>\mathrm{Cd}>\mathrm{Hg}$. 
Table 1

Trace metal concentration in three body parts of $M$. galloprovincialis from three biotopes $\left(\mu \mathrm{g} \cdot \mathrm{g}^{-1} \mathrm{~d} . \mathrm{w}.\right)$ and in the seawater environment $\left(\mu \mathrm{g} \cdot \mathrm{L}^{-1}\right)$

\begin{tabular}{|c|c|c|c|c|c|c|c|c|c|c|c|}
\hline & Station 1 & & & & Station 2 & & & Station 3 & & & \\
\hline & $\begin{array}{l}\text { Soft } \\
\text { tissues }\end{array}$ & Byssus & $\begin{array}{l}\text { Shell } \\
\text { liquor }\end{array}$ & Seawater & Soft tissues & Byssus & $\begin{array}{l}\text { Shell } \\
\text { liquor }\end{array}$ & Soft tissues & Byssus & $\begin{array}{l}\text { Shell } \\
\text { liquor }\end{array}$ & s \\
\hline $\mathrm{Zn}$ & $88.7 \pm 11.9$ & $98.32 \pm 18.85$ & $6.91 \pm 2.3$ & $27.98 \pm 5.4$ & $131.43 \pm 20.2$ & $145.86 \pm 9.59$ & $5.31 \pm 1.32$ & $111.62 \pm 14.84$ & $121.1 \pm 18.59$ & $19.7 \pm 5.3$ & 1 \\
\hline $\mathrm{Cu}$ & $7.8 \pm 3.6$ & $37.36 \pm 8.54$ & $2.19 \pm 1.7$ & $15.27 \pm 3.5$ & $12.47 \pm 3.4$ & $45.22 \pm 6.77$ & $3.1 \pm 0.51$ & $10.59 \pm 3.56$ & $25.22 \pm 6.77$ & $5.42 \pm 1.7$ & 2 \\
\hline As & $6.0 \pm 0.88$ & $5.37 \pm 1.87$ & $1.96 \pm 0.69$ & $47.84 \pm 8.9$ & $7.79 \pm 2.42$ & $4.97 \pm 0.86$ & $1.56 \pm 0.45$ & $5.5 \pm 0.44$ & $4.1 \pm 1.1$ & $2.1 \pm 0.9$ & 4 \\
\hline $\mathrm{Ni}$ & $3.94 \pm 1.69$ & $39.38 \pm 10.72$ & $1.24 \pm 1.66$ & $7.37 \pm 2.5$ & $4.2 \pm 1.37$ & $44.49 \pm 7.69$ & $0.43 \pm 0.26$ & $3.43 \pm 2.45$ & $24.49 \pm 7.69$ & $2.4 \pm 0.9$ & 1 \\
\hline $\mathrm{Pb}$ & $1.7 \pm 0.26$ & $3.4 \pm 0.8$ & $0.92 \pm 0.35$ & $1.28 \pm 0.38$ & $2.89 \pm 1.01$ & $5.36 \pm 1.61$ & $0.66 \pm 0.18$ & $2.95 \pm 1.32$ & $12.64 \pm 3.3$ & $0.49 \pm 0.15$ & 1 \\
\hline $\mathrm{Cd}$ & $1.1 \pm 0.16$ & $3.27 \pm 0.94$ & $1.28 \pm 0.5$ & $2.05 \pm 0.42$ & $1.5 \pm 0.4$ & $2.1 \pm 0.71$ & $0.45 \pm 0.22$ & $1.5 \pm 0.3$ & $0.73 \pm 0.12$ & $0.2 \pm 0.08$ & 1 \\
\hline $\mathrm{Cr}$ & $1.1 \pm 0.16$ & $1.52 \pm 0.50$ & $0.18 \pm 0.21$ & $4.39 \pm 1.1$ & $1.49 \pm 0.43$ & $1.73 \pm 0.22$ & $1.2 \pm 0.94$ & $1.2 \pm 0.4$ & $2.24 \pm 0.4$ & $0.8 \pm 0.2$ & 1 \\
\hline Co & $0.35 \pm 0.07$ & $0.98 \pm 0.39$ & $0.22 \pm 0.17$ & $2.20 \pm 0.46$ & $0.45 \pm 0.07$ & $1.39 \pm 0.2$ & $0.15 \pm 0.01$ & $0.23 \pm 0.16$ & $0.39 \pm 0.1$ & $0.1 \pm 0.008$ & 2 \\
\hline $\mathrm{Hg}$ & $0.09 \pm 0.01$ & $0.1 \pm 0.04$ & $0.18 \pm 0.04$ & $0.04 \pm 0.02$ & $0.19 \pm 0.07$ & $0.11 \pm 0.02$ & $0.22 \pm 0.06$ & $0.05 \pm 0.009$ & $0.06 \pm 0.02$ & $0.27 \pm 0.08$ & 0 \\
\hline
\end{tabular}

The shell liquor has low trace element concentrations at all stations (Table 1). However, the level of $\mathrm{Hg}$ in it is higher than in the other body parts (up to $71 \%$ among the three ones), which indicates that the liquor makes a considerable contribution to the mercury excretion for the organism detoxification.

\subsection{Multivariate analysis of element concentrations}

The overall trace element distributions in all the three body parts of the animals are significantly different $(P<0.05, P E R M A N O V A)$ at all the three stations (Table S2, Supplementary Material). There are no significant differences in the element content dispersions when sampling location is used as group factor $(P=0.5641$, PERMDISP), and it can be asserted that the overall element levels are significantly different at the three stations. However, the dispersions with the body part type as group factor (except for the byssus - shell liquor pair) are significantly heterogeneous $(P=0.0102$, $P E R M D I S P)$, and it cannot be unequivocally stated whether the differences in the distributions are due to the mean element levels or dispersions.

In soft tissues and byssus of M. galloprovincialis, there are significant differences in the overall element contents among the stations $(P=0.0037$ and $\mathrm{P}=0.0003$, respectively) with no significant differences in the dispersions (Tables S3 and S4). The pairwise PERMANOVA for the soft tissues shows significant differences between Stations 1 and 2 and between Stations 1 and 3 (Table S3). The analogous test for byssus indicates significant differences between Stations 1 and 2 and between Stations 2 and 3 (Table S4). There are no significant differences in the shell liquor trace element levels among the stations (P=0.2092, Table S5).

Principal component analysis (Fig. 3) applied to the square-root-transformed standardized element contents in soft tissues and byssus shows that the vectors of all elements are oriented in the positive direction of principal component 1 (PCO1), which characterizes the overall accumulation of the elements in the mussel parts. For both soft tissues and byssus, PCO1 accounts for $>40 \%$ of the dispersion. Principal component 2 (PCO2) explains $16-22 \%$ of the total variation. The negative direction of PCO2 is associated with $\mathrm{Zn}, \mathrm{As}, \mathrm{Cd}, \mathrm{Pb}, \mathrm{Hg}$, and in the positive direction of PCO2, there are vectors of $\mathrm{Co}$, Ni, $\mathrm{Cr}$ for soft tissues and $\mathrm{Co}, \mathrm{Ni}$, Cu for byssus. It appears that the PCO2 is related to the station location: its positive half-plane is dominated mostly by the observations from Station 1, and in its negative half-plane are mainly the Station-2 points. The data for Station 3 are in between and largely close to PCO2 = 0 . This illustrates the overall element accumulation in mussel tissues increasing from Station 1 through Station 3 to Station 2. Interestingly, sampling location, and thus, different element levels in the environment, was not the main factor determining the dispersion of the points. It is likely that the biological characteristics such as sexual differentiation and gonadal ripening played a major role in the different element accumulation in mussels collected at sampling sites not too far away from each other (about $7 \mathrm{~km}$ between Station 1 and Station 3).

Fig. 4 demonstrates the results of principal component analysis of square-root-transformed standardized trace element data assorted according to the body part type, with both the element contents (Fig. 4a) and sampling location (Fig. 4b) used as variables. In both cases, most of observations related to a certain body part type are bunched in clusters separated from each other. This feature allows deciding which body part a particular suite of element contents originates from. By analogy with Fig. 3, PCO1 in Fig. 4a explaining 44.3\% of the total variation is determined by the overall element accumulation (mainly associated with $\mathrm{Pb}, \mathrm{Cr}, \mathrm{Cu}, \mathrm{Ni}, \mathrm{Co}$, whose vectors are close to the positive direction of PCO1) in mussel body parts, from shell liquor to byssus. The greatest contribution to PCO2 explaining $23.4 \%$ of the total variation is made by the chalcophilic elements $\mathrm{Cd}, \mathrm{As}, \mathrm{Zn}, \mathrm{Hg}$, which tend to be more concentrated in shell liquor and/or soft tissues. If the variable is sampling location (Fig. 4b), PCO1 explains $58.4 \%$ of the total variation and is related to all the three body parts, with shell liquor and byssus making the largest contribution, whereas PCO2 explaining $23.7 \%$ of the total variation is associated mainly with the element content dispersion in shell liquor. This indicates that it is the trace element composition in shell liquor that is most strongly affected by the station location. The vectors in Fig. 4b shifted to the origin point to the body parts in which the highest contents of the respective elements are observed: $\mathrm{Cr}$, $\mathrm{Co}$, $\mathrm{Ni}$, $\mathrm{Cu}$, $\mathrm{Pb}$ in byssus; Zn, As, Cd in soft tissues; and $\mathrm{Hg}$ in shell liquor.

\subsection{Human health risk assessment}

Given the potential hazards to human health from the trace element intake, trace elements in cultivated mussels were compared with maximum permissible trace element levels in edible mollusks from the European, Turkish and Russian regulations. The measured contents of $\mathrm{Cu}, \mathrm{As}, \mathrm{Hg}, \mathrm{Pb}$, and $\mathrm{Zn}$ in the mussels' 
soft tissues did not exceed the maximum permissible levels, but the Cd content was above the level set in the Turkish regulations (Table 2).

It was found that EDI for all elements under consideration were lower than the corresponding reference values (RfD, PTDI, UDI). THQ and HI calculated from EDI according to Eqs. (1)-(3) were well below one, which indicate no likely health risk from consuming soft tissues of M. galloprovincialis harvested on the mollusk farm.

Table 2

Measured trace element contents and estimated daily intakes with soft tissues of $M$. galloprovincialis from the mollusk farm against upper tolerable levels and doses ( $\mathrm{Rf}_{0}, \mathrm{PTDI}$, and UDI) established in different regulations. Target hazard quotients (THQ) and hazard index (HI) are given in the last column

\begin{tabular}{|c|c|c|c|c|c|c|c|c|c|}
\hline & $\begin{array}{l}\text { Contents, } \\
\mu \mathrm{g} \cdot \mathrm{g}^{-1} \\
\text { w.w. }^{\mathrm{a}}\end{array}$ & $\begin{array}{l}\text { European } \\
\text { regulations, } \mu g \cdot g^{-1} \\
\text { w.w. }(E C, 2006)\end{array}$ & $\begin{array}{l}\text { Russian regulations, } \\
\mu \mathrm{g} \cdot \mathrm{g}^{-1} \text { w.w. (SanPiN, } \\
1992 \text { ) }\end{array}$ & $\begin{array}{l}\text { Turkish guidelines, } \\
\mu \mathrm{g} \cdot \mathrm{g}^{-1} \text { w.w. (Dural et } \\
\text { al. 2007) }\end{array}$ & $\begin{array}{l}\text { EDI', } \\
\mathrm{mg} \cdot \mathrm{kg}^{-1} \\
\text { b.w. day }{ }^{-1}\end{array}$ & $\begin{array}{l}\mathrm{RfD}_{\mathrm{o}} \\
\mathrm{mg} \cdot \mathrm{kg}^{-1} \\
\text { b.w. } \cdot \text { day }^{-1}\end{array}$ & $\begin{array}{l}\text { PTDI, } \\
\mathrm{mg} \cdot \mathrm{kg}^{-1} \\
\text { b.w. day }\end{array}$ & $\begin{array}{l}\text { UDI, } \\
{\mathrm{mg} \cdot \mathrm{kg}^{-1}}^{\text {b.w. } \text { day }^{-1}}\end{array}$ & THQ \\
\hline $\mathrm{Zn}$ & 19.29 & - & 200 & 50 & $7.3 \cdot 10^{-4}$ & 0.3 & 1 & 0.36 & $2.4 \cdot 10^{-3}$ \\
\hline $\mathrm{Cu}$ & 1.70 & - & 30 & 20 & $4.5 \cdot 10^{-5}$ & 0.04 & 0.5 & 0.07 & $1.1 \cdot 10^{-3}$ \\
\hline As & 1.30 & - & 2 & - & $5.1 \cdot 10^{-5}$ & 0.0003 & 0.002 & - & $1.5 \cdot 10^{-2 c}$ \\
\hline $\mathrm{Ni}$ & 0.74 & - & - & - & $3.1 \cdot 10^{-5}$ & 0.002 & 0.003 & 0.0004 & $1.6 \cdot 10^{-3}$ \\
\hline $\mathrm{Pb}$ & 0.37 & 1.5 & 10 & 10 & $1.4 \cdot 10^{-5}$ & 0.002 & 0.004 & - & $6.8 \cdot 10^{-3}$ \\
\hline $\mathrm{Cr}$ & 0.27 & - & - & - & $8.4 \cdot 10^{-6}$ & - & - & - & - \\
\hline $\mathrm{Cd}$ & 0.24 & 1.0 & 2 & 0.1 & $9.5 \cdot 10^{-6}$ & 0.001 & 0.001 & 0.0004 & $9.5 \cdot 10^{-3}$ \\
\hline Co & 0.08 & - & - & - & $2.7 \cdot 10^{-6}$ & 0.0003 & - & 0.0002 & $9.0 \cdot 10^{-3}$ \\
\hline $\mathrm{Hg}$ & 0.02 & - & - & 0.5 & $7.1 \cdot 10^{-7}$ & 0.0003 & 0.0006 & 0.0006 & $2.4 \cdot 10^{-3}$ \\
\hline $\mathrm{HI}$ & & & & & & & & & $4.8 \cdot 10^{-2}$ \\
\hline \multicolumn{10}{|c|}{${ }^{a}$ factor of conversion from dry to wet weight (w.w.) is 4.6} \\
\hline \multicolumn{10}{|c|}{${ }^{b}$ factor of conversion from dry to cooked weight is 3.82 (Biandolino et al. 2021) } \\
\hline
\end{tabular}

\section{Discussion}

M. galloprovincialis can absorb trace elements from water, as well as ingest with phytoplankton and other suspended particles entering the digestive system (Haryono and Kilawati, 2017; Mikac et al. 1996). Trace element entering the food chain can be accumulated in the mollusk tissues to hazardous levels and be harmful to mollusk consumers' health (Manahan 2000). Cd, Pb, $\mathrm{Hg}$ and inorganic As have a negative impact on organisms and are harmful even in trace amounts. They cannot be metabolized into harmless forms and are accumulated in the human body over time causing chronic illness and other health problems (Myriam 2021; Stankovic and Jovic 2012). In the present study, the content of the most toxic elements in soft tissues of M. galloprovincialis from the Black Sea decreased in the following order: As $>\mathrm{Pb}>\mathrm{Cd}>\mathrm{Hg}$. The same distribution was observed for M. galloprovincialis from the southeastern Adriatic, Montenegro (Stankovic et al. 2011).

As emphasized in (Horne 1969), the seawater of different oceans and seas contains all trace elements. Their concentrations increase in coastal waters, which are under impact of many anthropogenic factors. The mussel sampling sites under study (Fig. 1) are affected by numerous discharges, including untreated domestic wastewater, shipyard and dock effluents, storm water outlets, urban industrial emissions, farmland runoff (containing fertilizers and pesticides), and sewage of fleet stationed in city bays (Gruzinov et al. 2019; Smirnova and Riabinin, 2013). As mentioned in Materials and Methods, seawater at Station 3 is more heavily polluted than at Station 1, which accounts for the higher trace element concentrations at Station 3 (Table 1).

In benthic mussels collected from the seafloor under the farm (Station 2), the trace element contents in soft tissues were highest. It was noted that seafloor sediments are the main repository of trace elements, including potentially hazardous metals, in marine environment (Okoro et al. 2012; Sakai et al. 1986). Consequently, sediments can be considered indicators of trace element pollution of aquatic environment. Although many trace elements, being micronutrients, are necessary for the normal physiological activity of aquatic organisms, many of them can be concentrated in excess of physiological requirements in soft tissues and become toxic (Briffa et al. 2020; Rouane-Hacene et al. 2015; Stankovic and Jovic 2012).

Growing mussels assimilate essential elements, which can be divided into two groups based on their levels in tissues (Horne 1969). The first group is the structural elements that are most abundant in mussel tissues and form organic and inorganic compounds in the mollusk tissues: shells, soft tissues, and byssal threads. The second group includes catalytic elements (micronutrients) that are present in small amounts, mainly as components of compounds that catalyze biochemical processes. Most of the trace elements under study ( $\mathrm{Cr}, \mathrm{Co}, \mathrm{Ni}, \mathrm{Cu}, \mathrm{Zn}, \mathrm{As}$ ) have low atomic numbers (from 24 to 33 ) and play a role in the 
functioning of marine organism cells, being minor constituents of proteins, carbohydrates, and lipids. lons of catalytic elements $\mathrm{Cu}, \mathrm{Zn}$, Cd, Co, Ni are enzyme activators (cofactors) (Horne 1969).

As shown in Fig. 2, considerable levels of $\mathrm{Zn} \mathrm{As,} \mathrm{Cd} \mathrm{were} \mathrm{observed} \mathrm{in} \mathrm{soft} \mathrm{tissues} \mathrm{and} \mathrm{byssus} \mathrm{of} \mathrm{mussels} \mathrm{from} \mathrm{the} \mathrm{biotopes} \mathrm{under} \mathrm{consideration.} \mathrm{Byssus} \mathrm{is}$ known to not only adsorb trace elements from seawater, but also to participate in the extraction of some elements from soft tissues (Koide et al. 1982; Szefer et al. 1999; Yap et al. 2003b). High abundances of some elements (Ni, Cu, Pb, Co) in byssus are associated with histidine and lysine residues, which are the components of byssal proteins. These elements form strong coordination bonds with histidine and lysine (Leberman and Rabin 1959; Naik et al. 2012; Yamauchi and Odani, 1996), which strengthen byssus (Babarro and Reiriz 2010; Lucas et al. 2002; Reinecke et al. 2017).

The content of $\mathbf{Z n}$ in soft tissues or byssus reached $40-45 \%$ of the total $\mathrm{Zn}$ accumulated in the studied body parts and varied in the range from 88.7 to 145.6 $\mu \mathrm{g} \cdot \mathrm{g}^{-1}$ d.w. (Table 1). The observed high levels of $\mathrm{Zn}$ in soft tissue are related to the essentiality of this trace element for mussels. $\mathrm{Zn}$ serves as a catalyst in many physiological processes; it regulates growth, development, reproduction and metabolic processes in mollusks (Franca et al. 2005; Viarengo et al. 1990). The content of $\mathrm{Zn}$ in byssus depends on its concentration in seawater and also in soft tissues as it can be extracted from the mussel body into byssus. Yap et al. (2005) noticed that if large amounts of heavy metals are accumulated in soft tissues of $M$. edulis, then the metals are transferred to byssus in almost equal proportions, and the same pattern was noted in the present research with respect to M. galloprovincialis (Table 1).

Cu was concentrated mostly in soft tissues and byssus. The low proportions of $\mathrm{Cu}$ in shell liquor (5-13\%) indicated little or no copper excretion through this fluid. The results showed that the Cu content in byssus reached $61-79 \%$ (Fig. 2). It is likely that this mussel body part can both concentrate copper from seawater and withdraw this metal from the mollusk tissues. Previously, Mytilus edulis was also shown to contain higher copper content in byssus than in soft tissue (Szefer et al. 1997). It is known that Cu ions, like Zn, in mollusks act as cofactors of some enzymes, playing a key role in their functioning (Horne 1969; Khristoforova et al. 1994). In particular, they stimulate polyphenol oxidase, ascorbate oxidase, and other enzymatic systems. The combined effect of excess zinc and copper leads to the destruction of mollusk mitochondria and suppresses sperm motility (Earnshaw 1986; Lyngby and Brix 1987). The major sources of $\mathrm{Cu}$ in the water body in question are wastewater, transport, copper-containing fertilizers and pesticides, welding and galvanization processes, and combustion of hydrocarbon fuels.

As is a metalloid that is rarely found in nature as a free element, but its compounds are found in air, water, soil and all living tissues (Kaur et al. 2011; Mayer et al. 1993). In aquatic organisms, arsenic occurs in organic and inorganic forms. Inorganic As compounds are highly toxic, whereas natural organoarsenicals are non-toxic (Neff 2002). The most important anthropogenic source of arsenic pollution off the southwestern coast of Crimea is chemical warfare burial sites with the warfare containing lewisite (Smirnova et al. 2005). Inorganic As is strongly carcinogenic. Depending on oxidation state, cell type, concentration and exposure, it can induce excessive apoptosis (Chiarelli and Roccheri 2014). In our study, the arsenic content in mussels from the mollusk farm did not exceed $1.3 \mu \mathrm{g} \cdot \mathrm{g}^{-1}$ W.w., which is below the maximum permissible level according to the Russian regulations (Table 2). In soft tissues of mussels, organic arsenic accounts for $91 \%$ of the total arsenic (Neff 2002). There is evidence that in the mollusk farm area, the As concentration in seawater exceeded the maximum permissible level; however, M. galloprovincialis did not accumulate this element in soft tissues in large amounts (Ryabushko et al. 2017), in agreement with our results.

In our studies, the highest As content was in soft tissues of benthic mussels (Station 2), which fact was noted also by Wu et al. (2014) for species sampled in the East China Sea: the closer the organism's habitat to the sediments, the higher the arsenic content in it. Despite the fact that the As content share in byssus reached as much as $40 \%$, its content in soft tissues was significantly higher than in byssus and shell liquor $\left(P=2 \cdot 10^{-4}\right.$ and $P=6 \cdot 10^{-5}$, respectively, Table $\left.S 6\right)$. Ünlü and Fowler (1979) noted that active secretion of arsenic in byssus of the mussel M. galloprovincialis contributes to the elimination of arsenic from the mussel body.

$\mathrm{Ni}$ is discharged into the aquatic environment mainly with municipal and industrial wastewaters. For some invertebrates, it is a trace element with essential biological role since they produce enzymes that contain Ni in active sites. However, in high concentrations, Ni is toxic (Chalkiadakis et al. 2013). It is known that nickel, along with cadmium and arsenic, inhibits DNA repair mechanisms (Lucas et al. 2002). In byssus, the Ni content percentage was highest among all the elements under study (Fig. 2), and it was 8-10 times higher than in soft tissues (Table 1). Earlier, Szefer et al. (2002) noted that among all metals (Hg, Cd, $\mathrm{Pb}, \mathrm{Ag}, \mathrm{Cu}, \mathrm{Zn}, \mathrm{Cr}, \mathrm{Ni}, \mathrm{Co}, \mathrm{Mn}$ и $\mathrm{Fe}$ ), Ni was deposited in greatest proportions in byssus of Mytilus edulis trossulus (southern Baltic) as compared with its soft tissues.

$\mathrm{Pb}$ is a heavy metal that is toxic to animals and humans. It damages nervous system and causes various disorders (Nava-Ruiz et al. 2012). The main source of lead in the environment is anthropogenic activity (in particular, this heavy metal is released from anti-fouling paints and acid batteries). Lead toxicity in marine invertebrates depends on species identity and its life stage (Chiarelli and Roccheri 2014). In the present research, at all stations, the Pb content in byssus of $M$. galloprovincialis was significantly higher than in its soft tissues $\left(\mathrm{P}<10^{-5}\right.$, Table S7), and we can suggest that this element is actively excreted through byssus. The highest percentage of $\mathrm{Pb}$ among the body parts was in byssus of $M$. galloprovincialis from Station 3 , up to $79 \%$ (Fig. $2 \mathrm{c}$ ). The high $\mathrm{Pb}$ concentration in this water area was apparently due to the shipbreaking plant activity and the inflow of the Chernaya River that can transport large amounts of $\mathrm{Pb}$ (Gruzinov et al. 2019). Thus, the results obtained support the idea that $M$. galloprovincialis byssus is an excellent indicator of the seawater pollution with lead. The Pb contents in soft tissues were comparable with other researchers' results obtained using mussels from the southwestern Black Sea (Bat et al. 2018; Belivermiş et al. 2016; Çulha et al. 2017).

$\mathrm{Cd}$ is a very toxic environmental pollutant and cell poison that causes different types of damage including cell death. A high percentage of its content was observed in soft tissues, up to $62 \%$ (Fig. 2c). Significant differences were found for the $\mathrm{Cd}$ content between soft tissues and byssus (P $=4 \cdot 10^{-4}$, Table S8). Also, significant differences in the Cd content were registered between soft tissues and shell liquor $\left(P=7 \cdot 10^{-4}\right)$, which suggest that shell liquor is not used for the removal of this toxicant. Li et al. (2006) noted that bivalves do not regulate Cd levels and usually accumulate this element. Cd is accumulated in cells by 
interacting with cellular components and molecular targets (Chiarelli and Roccheri 2014; Kingsley and Frazier 1979). In invertebrates, it stimulates the expression of antioxidant enzymes, metallothioneins and heat shock proteins. It inhibits the expression of digestive enzymes, esterases and phospholipases. $\mathrm{Cd}$ also affects tissue organization, immune responses, and cell cycles by inducing apoptosis (Sokolova et al. 2004). The relatively low levels of Cd as compared to higher levels of $\mathrm{Pb}$ in byssus may be a result of the more efficient transfer of $\mathrm{Pb}$ from soft tissues to byssus, as opposed to Cd, which is strongly accumulated in soft tissues in hepatopancreas (Szefer et al. 2006). The high content of cadmium in soft tissues of mussels appears to be related to its high levels in sediments in the adjacent bays (Gubanov et al. 2010).

Sources of $\mathrm{Cr}$ in the environment can be both anthropogenic and natural. Natural chromium occurs mainly in trivalent state, whereas hexavalent $\mathrm{Cr}$ (VI) in the environment originates almost entirely from human activities (Liang et al. 2021; Sacchi et al. 2021). This metal, especially in the hexavalent state, is a very toxic trace element posing certain threats to coastal ecosystems. Coastal chromium pollution is mainly due to the discharge of untreated or poorly treated industrial wastes. $\mathrm{Cr}(\mathrm{VI})$ is 30 times as toxic as $\mathrm{Cr}$ (III), and it is both mutagenic and carcinogenic (Natale et al. 2000). In the southwestern Crimea, the anthropogenic source of chromium can be shipyards and the shipbreaking plant, and the natural source of chromium is volcanic rocks of the Crimean peninsula.

The $\mathrm{Cr}$ content in our studies in soft tissues and byssus of M. galloprovincialis was more than twice as low as in Mytilus edulis trossulus from polluted waters of the Gulf of Gdańsk, Poland (Szefer et al. 2002). Our results showed that the content of $\mathrm{Cr}$ in byssus was significantly higher than that in soft tissues ( $\mathrm{P}<$ $1 \cdot 10^{-5}$, Table S9). Earlier, the same pattern was noted for $M$. edulis trossulus from the Gulf of Gdańsk, and byssus was recommended for use in chromium pollution biomonitoring (Szefer et al. 2002). It is known that $\mathrm{Cr}(\mathrm{VI})$ significantly affects the functional and structural parameters of mussel gills, and this indicates that this tissue is the main target of the $\mathrm{Cr}(\mathrm{VI})$ exposure (Ciacci et al. 2012). There is evidence of the effect of $\mathrm{Cr}(\mathrm{VI})$ in vitro on immune system of M. galloprovincialis (Barmo et al. 2011). In M. edulis, the DNA chain breaks in the gill cells under the influence of $\mathrm{Cr}$ (VI) (Emmanouil et al 2007). An increase in the total content of $\mathrm{Cr}(\mathrm{VI})$ in tissues and destabilization of lysosomal membranes were observed in digestive gland of $M$. galloprovincialis treated with a high concentration of this heavy metal $\left(100 \mu \mathrm{g} \cdot \mathrm{L}^{-1}\right)$, and oxidative stress occurred in this organ (Barmo et al. 2011).

Co is an important component of vitamin $\mathrm{B}_{12}$ and a cofactor for several enzymes (Lehninger 1976; Nolan and Dahlgaard 1991). In all the water areas under study, cobalt was slightly more accumulated in soft tissues (up to $32 \%$ among the three body parts). In relatively low concentrations, this trace element becomes toxic. In mammals, it can induce apoptosis, necrosis, or inflammatory response in the body and is genotoxic (Briffa et al. 2020).

Co was accumulated and extracted mainly by byssus and, to a slight extent, by shell liquor (Table 1, Fig. 2). Significant differences in the Co content were found between soft tissues and byssus $\left(P=2 \cdot 10^{-5}\right.$, Table S10). As shown by Szefer et al. (2006), mytilids from industrialized regions also showed higher concentrations of $\mathrm{Co}$ in byssus than in soft tissues. Byssus of M. edulis was proposed to be used in Co pollution biomonitoring (Szefer et al. 1999).

There are three chemical forms of $\mathrm{Hg}$ in the environment: elemental, organic, and inorganic. These forms are mutually transformable into each other, and they all can cause systemic toxicity (Graeme and Pollack 1998). Hg can occur naturally in the environment or come from anthropogenic sources. A significant fraction of $\mathrm{Hg}$ is volatilized and returns to the atmosphere, but much of this metal entering the coastal areas precipitates due to very low solubility of its compounds (Stankovic and Jovic 2012). Anthropogenic sources of $\mathrm{Hg}$ in the water areas under consideration can be ballast discharge from submarines and domestic wastewater. Natural sources of mercury include numerous methane seeps off coasts of southwestern Crimea and in bays of Sevastopol (Egorov et al. 2011). This element is accumulated in sediments, which are its main sink. It was noted that most of the inorganic and organic Hg compounds in the aquatic environment are adsorbed on suspended matter and settle to the bottom (Schiff 2000). For this reason, the highest content of mercury in soft tissue was found in mussels sampled from the seafloor under the farm. In sediments, bacteria can convert inorganic mercury to methylmercury, the most toxic Hg compound (Harada et al. 1998).

In our study, the mercury contents in soft tissues and byssus were below $0.2 \mu \mathrm{g} \cdot \mathrm{g}^{-1}$ (Table 1). The same pattern was observed for $M$. galloprovincialis from the Cantabrian coast (Bartolome 2010). It should be noted that in M. galloprovincialis, $\mathrm{Hg}$ was removed from soft tissues mainly through shell liquor (up to $71 \%$ ). Our results show that the function of byssus and shell liquor in $M$. galloprovincialis, among others, is to protect its vitals by extracting and excreting toxic trace elements.

\section{Conclusions}

In the present study, the distribution of trace elements ( $\mathrm{Cd}, \mathrm{Cu}, \mathrm{As}, \mathrm{Ni}, \mathrm{Hg}, \mathrm{Pb}, \mathrm{Zn}, \mathrm{Cr}, \mathrm{Co})$ in soft tissues, byssus, and shell liquor of the mussel $\mathrm{M}$. galloprovincialis living in the coastal waters of the Black Sea off southwestern Crimea has been studied. At all the sampling stations, the highest content has been noted for $\mathrm{Zn}$ (up to $131.4 \pm 20.2 \mu \mathrm{g} \cdot \mathrm{g}^{-1} \mathrm{~d}$.w.). The trace element contents in soft tissues of $M$. galloprovincialis at all stations have been found to decrease in the following order: $\mathrm{Zn}>\mathrm{Cu}>\mathrm{As}>\mathrm{Ni}>\mathrm{Pb}>\mathrm{Cd}>\mathrm{Cr}>\mathrm{Co}>\mathrm{Hg}$. The contents of $\mathrm{Cd}, \mathrm{Cu}, \mathrm{As}, \mathrm{Hg}, \mathrm{Pb}$, and $\mathrm{Zn}$ in soft tissues of the cultured mussels did not exceed the permissible levels according to different regulations, except for $\mathrm{Cd}$ that exceeded the maximum level established in Turkish guidelines. When comparing the estimated daily intakes (EDI) of these elements with tolerable values set by international authorities (WHO, European Commission, USEPA), it has been found that EDI for all the elements were below the threshold values, indicating no likely risks of consuming the mussels cultivated on the mollusk farm.

The results have shown that the contents of the trace elements in question in soft tissues, byssus, and shell liquor of the mussels from different biotopes decreased in the following order: Station 2 (seafloor under the mollusk farm) > Station 3 (innermost part of Sevastopol Bay) > Station 1 (mollusk farm). The proximity of the sediments appears to be the most important factor affecting the element accumulation. Significant differences have been registered in the overall element contents in M. galloprovincialis from the three stations under study. Principal component analysis has shown a tendency of the data points to clustering with the location as the grouping factor. 
A similar clustering tendency has been observed when the grouping factor is body part type. However, in this case the analysis of variance has not allowed judging about the differences in the overall element levels in the three body parts (except for the byssus - shell liquor pair, in which byssus has significantly higher element contents) due to the significantly inhomogeneous dispersions.

The contents of individual elements vary significantly in different mussel body parts. For example, Zn, Cd, and As have been found to have the largest shares in soft tissues: $44-63 \%, 34-62 \%$, and 45-54\%, respectively. Byssus has been characterized with the highest percentages of many trace element contents: Ni (81$91 \%), \mathrm{Cu}(61-79 \%), \mathrm{Pb}(57-79 \%)$ and $\mathrm{Co}(54-69 \%)$. This organ performs the function of not only attachment to the substrate, but also extracts heavy metals from soft tissues. Byssus of $\mathrm{M}$. galloprovincialis is a better bioindicator of the environment pollution with $\mathrm{Ni}, \mathrm{Cu}, \mathrm{Pb}, \mathrm{Co}$, and $\mathrm{Cr}$ than its soft tissues.

For the first time, trace elements have been quantified in shell liquor and the role of shell liquor as a detoxifying system has been demonstrated in this study. The highest content of mercury in shell liquor (up to $71 \%$ among the body parts) suggests that this contaminant is efficiently accumulated and removed from the organism through this fluid.

The data analysis has shown the need for the further study of the role of byssus in the distribution of trace elements in mussel tissues. In particular, the question about the ratio of the accumulating (from the external environment) and eliminating (from the mussel body) functions of byssus remains open.

\section{Declarations}

Acknowledgments The authors are grateful to Dr. Nelya P. Kovrigina for providing the data on the trophic index TRIX.

Authors' contributions CNS and PMA took part in collecting material, setting up and conducting the experiment, processing the data obtained and discussing the materials. KSV edited the final version of the manuscript, and contributed to the ICP-MS and data analysis. SLL contributed to the data analysis. BNI prepared analytical samples and contributed to the ICP-MS analysis.

Funding This work was supported by the Ministry of Science and Higher Education of the Russian Federation (grant numbers $121030300149-0$ and AAAAA19-119031490078-9).

Data Availability The datasets used and analyzed during the current study are available from the corresponding author on reasonable request.

\section{Compliance with ethical standards}

Ethics approval Ethical approval were observed during the experiment. All sampling was conducted in accordance with the Russia Federation law on harvest of biological resources in natural waters.

Consent to participate All authors consent to participate

Consent for publication All authors consent to publication

Competing interests The authors declare that they have no competing interests

\section{References}

1. Adams WJ, Rowland CD (2003) Aquatic toxicology test methods. In: Hoffman DJ, Rattner BA, Burton GA, Cairns J (eds) Handbook of Ecotoxicology. Lewis Publishers, Boca Raton, pp 19-43. https:// doi.org/10.1201/9781420032505

2. Atasaral ŞŞ, Romero MR, Cueto R, González-Lavín N, Marcos M, Diz AP (2015) Subtle tissue and sex-dependent proteome variation in mussel (Mytilus galloprovincialis) populations of the Galician coast (NW Spain) raised in a common environment. Proteomics 15(23-24):3993-4006.

https://doi.org/10.1002/pmic.201500241

3. Babarro JMF, Reiriz FMJ (2010) Secretion of byssal threads in Mytilus galloprovincialis: Quantitative and qualitative values after spawning stress. Journal of Comparative Physiology B 180(1):95-104. https://doi.org/10.1007/s00360-009-0392-y

4. Barmo C, Ciacci, C, Fabbri R, Olivieri S, Bianchi N, Gallo G, Canesi L (2011) Pleiotropic effects of hexavalent chromium (Cr VI) in Mytilus galloprovincialis digestive gland. Chemosphere 83(8):1087-1095. https://doi.org/10.1016/j.chemosphere.2011.01.037

5. Bartolomé L, Navarro P, Raposo JC, Arana G, Zuloaga O, Etxebarria N, Soto M (2010) Occurrence and distribution of metals in mussels from the Cantabrian coast. Archives of Environmental Contamination and Toxicology 59:235-243. https://doi.org/10.1007/s00244-010-9476-7

6. Bat L, Öztekin HC (2016) Heavy metals in Mytilus galloprovincialis, Rapana venosa and Eriphia verrucosa from the Black Sea coasts of Turkey as bioindicators of pollution. Walailak Journal of Science and Technology 13(9):715-728

7. Bat L, Sahin, F, Öztekin A. (2018) Toxic elements in edible mollusks from Igneada coasts of the Black Sea, Turkey. Korean Journal of Food and Health Convergence 4:22-31. https://doi.org/10.13106/kjfhc.2018.vol4.no3.22

8. Belivermiş M, Kılıç Ö, Çotuk Y (2016) Assessment of metal concentrations in indigenous and caged mussels (Mytilus galloprovincialis) on entire Turkish coastline. Chemosphere 144:1980-1987. https://doi.org/10.1016/j.chemosphere.2015.10.098

9. Biandolino F, Parlapiano I, Denti G, Di Nardo V, Prato E (2021) Effect of different cooking methods on lipid content and fatty acid profiles of Mytilus galloprovincialis. Foods 10(2):416. https://doi.org/10.3390/foods10020416

10. Boening DW (1999) An evaluation of bivalves as biomonitors of heavy metals pollution in marine waters. Environmental Monitoring and Assessment 55:459 -470. https://doi.org/10.1023/A:1005995217901 
11. Boltachev AR, Karpova EP, Danilyuk ON (2010) Peculiarities of thermohaline parameters and ichthyocenosis of the Chernaya river estuary (the Sevastopol Bay). Marine Ecological Journal 2(9):23-36 (in Russian)

12. Briffa J, Sinagra E, Blundell R (2020) Heavy metal pollution in the environment and their toxicological effects on humans. Heliyon 6(9):2-26. https://doi.org/10.1016/j.heliyon.2020.e04691

13. Cantillo AY (1998) Comparison of results of mussel watch programs of the United States and France with worldwide mussel watch studies. Marine Pollution Bulletin 36(9):712-717. https://doi.org/10.1016/S0025-326X(98)00049-6

14. Casas S, Gonzalez JL, Andral B, Cossa D (2008) Relation between metal concentration in water and metal content of marine mussels (Mytilus galloprovincialis): impact of physiology. Environmental Toxicology and Chemistry 27:1543-1552. https://doi.org/10.1897/07-418.1

15. Chalkiadakis O, Paraskevopoulou V, Roussos I, Dassenakis M, Simantiris LN (2013) Comparative study of the accumulation of Ni in different tissues of mussels and soft clams. E3S Web of Conferences 1:11003. https://doi.org/10.1051/e3sconf/20130111003

16. Chelyadina NS, Pospelova N, Kopytov YuP (2015) Distribution of copper in the tissues of males and females of Mytilus galloprovincialis. Hydrobiological Journal 51(4):74-79. https://doi.org/10.1615/HydrobJ.v51.i4.90

17. Chelyadina NS, Smirnova LL (2018) Content of ascorbic acid, calcium, copper, and zinc in the interstitial fluid of cultivated mussel Mytilus galloprovincialis Lam. in waters of the south-west coast of Crimea. Scientific Notes of V.I. Vernadsky Crimean Federal University. Biology. Chemistry 70(4):237-246 (in Russian)

18. Chemnitzer R (2019) Strategies for achieving the lowest possible detection limits in ICP-MS. Spectroscopy 34(10):12-16.

19. Chiarelli R, Roccheri MC (2014) Marine invertebrates as bioindicators of heavy metal pollution. Open Journal of Metal 4:93-106. https://doi.org/10.4236/ojmetal.2014.44011

20. Ciacci C, Barmo C, Gallo G, Maisano M, Cappello T, D’Agata A, Leonzio C, Mauceri A, Fasulo S, Canesi L (2012) Effects of sublethal, environmentally relevant concentrations of hexavalent chromium in the gills of Mytilus galloprovincialis. Aquatic Toxicology 120:109-118. https://doi.org/10.1016/j.aquatox.2012.04.015

21. Clarke KR, Gorley RN, Somerfield PJ, Warwick RM (2014) Change in Marine Communities: An Approach to Statistical Analysis and Interpretation, 3rd ed. PRIMER-E, Plymouth

22. Coombs TL, Keller PJ (1981) Mytilus byssal threads as an environmental marker for metals. Aquatic Toxicology 1(5-6):291-300. https://doi.org/10.1016/0166-445X(81)90023-0

23. Çulha ST, Çulha M, Karayücel I, Çelik MY, Işler Y (2017) Heavy metals in Mytilus galloprovincialis, suspended particulate matter and sediment from offshore submerged longline system, Black Sea. International Journal of Environmental Science and Technology 14:385-396.

https://doi.org/10.1007/s13762-016-1158-1

24. Dural M, Göksu MZ, Özak AA (2007) Investigation of heavy metal levels in economically important fish species captured from the Tuzla lagoon. Food Chemistry 102(1):415-421. https://doi.org/10.1016/j.foodchem.2006.03.001

25. Earnshaw MJ, Wilson S, Akberali HB, Butler RD, Marriott KRM (1986) The action of heavy metals on the gametes of the marine mussel, Mytilus edulis (L.) -III. The effect of applied copper and zinc on sperm motility in relation to ultrastructural damage and intracellular metal localization. Marine Environmental Research 20(4):261-268. https://doi.org/10.1016/0141-1136(86)90052-8

26. EC (Commission of the European Communities) (2006) Commission Regulation (EC) No 1881/2006 of 19 December 2006 setting maximum levels for certain contaminants in foodstuffs. Official Journal of the European Union L364:5-24

27. EFSA (2006) Tolerable upper intake levels for vitamins and minerals; European Food Safety Authority

28. Egorov VN, Artemov Yu.G, Gulin SB (2011) Methane Seeps in the Black Sea - Environmental and Ecological Role. EKOSI-Gidrofizika, Sevastopol (in Russian)

29. Emmanouil, C., Sheehan, T.M. and Chipman, J.K. (2007) Macromolecule oxidation and DNA repair in mussel (Mytilus edulis L.) gill following exposure to $\mathrm{Cd}$ and $\mathrm{Cr}(\mathrm{VI})$. Aquatic Toxicology 82(1):27-35. https://doi.org/10.1016/j.aquatox.2007.01.009

30. FAO Fisheries and Aquaculture Division (2021) Cultured aquatic species information programme: Mytilus galloprovincialis (Lamark, 1819). http://www.fao.org/fishery/culturedspecies/Mytilus_galloprovincialis/en. Retrieved October 20, 2021.

31. FAO/WHO (2011) Evaluation of Certain Food Additives and Contaminants: Seventy-second Report of the Joint FAO/WHO Expert Committee on Food Additives. World Health Organization, Geneva

32. Filippini T, Tancredi S, Malagoli C, Malavolti M, Bargellini A, Vescovi L, Nicolini F, Vinceti M (2020) Dietary estimated intake of trace elements: Risk assessment in an Italian population. Exposure and Health 12:641-655. https://doi.org/10.1007/s12403-019-00324-w

33. França S, Vinagre C, Caçador I, Cabral, HN (2005) Heavy metal concentrations in sediment, benthic invertebrates and fish in three salt marsh areas subjected to different pollution loads in the Tagus Estuary (Portugal). Marine Pollution Bulletin 50(9):9931018. https://doi.org/10.1016/j.marpolbul.2005.06.040

34. Gosling EM (2003) Bivalve Molluscs: Biology, Ecology and Culture. Blackwell, Oxford, UK

35. Graeme KA, Pollack JrCV (1998) Heavy metal toxicity, Part I: arsenic and mercury. The Journal of Emergency Medicine 16: 45-56. https://doi.org/10.1016/S0736-4679(97)00241-2

36. Gruzinov VM, Dyakov NN, Mezenceva IV, Malchenko YuA, Zhohova NV, Korshenko AN (2019) Sources of coastal water pollution near Sevastopol. Oceanology 59:523-532. https://doi.org/10.1134/S0001437019040076

37. Gubanov VI, Kopytov YuP, Bobko NI (2010) Assessment of bottom sediments in Crimea coastal regions pollution by heavy metals. Marine Ecological Journal 9(4):38-47 (in Russian) 
38. Gupta SK, Singh J (2011) Evaluation of mollusc as sensitive indicatior of heavy metal pollution in aquatic system: a review. IIOAB Journal 2(1):49-57

39. Harada M, Nakanishi J, Konuma S, Ohno K, Kimura T, Yamaguchi H, Tsuruta K, Kizaki T, Ookawara T, Ohno H (1998) The present mercury contents of scalp hair and clinical symptoms in inhabitants of the Minamata area. Environmental Research 77(2):160-164._https://doi.org/10.1006/enrs.1998.3837

40. Haryono MG, Mulyanto, Kilawati dY (2017) Heavy metal Pb content in the seawater, sediment and green mussel tissue Perna viridis. Jurnal IImu dan Teknologi Kelautan Tropis 9(1):1-7. https://doi.org/10.29244/jitkt.v9i1.17864

41. Horne BA (1969) Marine Chemistry: The structure of Water and the Chemistry of the Hydrosphere. Wiley, New York.

42. Ivanov VN, Kholodov VI, Senicheva MI, Pirkova AV, Bulatov KV (1989) Biology of Cultivated Mussels. Naukova dumka, Kiev (in Russian)

43. Kapranov SV, Karavantseva NV, Bobko NI, Ryabushko VI, Kapranova LL. (2021a) Element contents in three commercially important edible mollusks harvested off the southwestern coast of Crimea (Black Sea) and assessment of human health risks from their consumption. Foods 10(10): 2313. https://doi.org/10.3390/foods10102313

44. Kapranov SV, Karavantseva NV, Bobko N.I, Ryabushko VI, Kapranova LL (2021b) Sex-and sexual maturation-related aspects of the element accumulation in soft tissues of the bivalve Mytilus galloprovincialis Lam. collected off coasts of Sevastopol (southwestern Crimea, Black Sea). Environmental Science and Pollution Research 28(17): 21553-21576. https://doi.org/10.1007/s11356-020-12024-z

45. Kaur S, Kamli MR, Ali A (2011) Role of arsenic and its resistance in nature. Canadian Journal of Microbiology 57:769-774. https://doi.org/10.1139/w11062

46. Kholodov VI, Pirkova AV, Ladygina LV (2017) Cultivation of Mussels and Oysters in the Black Sea. LLC Izdat-Print Publishing House, Voronezh (in Russian)

47. Khristoforova NK, Shulkin VM, Kavun VYa, Chernova EN (1994) Heavy Metals in Commercial and Cultivated Mollusks in the Peter the Great Bay. Dalnauka, Vladivostok (in Russian)

48. Kingsley BS, Frazier JM (1979) Cadmium transport in isolated perfused rat liver: zinc-cadmium competition. American Journal of Physiology 236:139143. https://doi.org/10.1152/ajpcell.1979.236.3.C139

49. Koide M, Lee DS, Goldberg ED (1982) Metals and transuranic records in mussel shells, byssal threads and tissues. Estuarine, Coastal and Shelf Science 15(6):679-695. https://doi.org/10.1016/0272-7714(82)90079-8

50. Kuftarkova EA, Gubanov VI, Kovrigina NP, Eremin IYu, Senicheva MI (2006) Ecological assessment of modern state of waters in the region of interaction of the Sevastopol bay and part of the sea contiguous to it.. Marine Ecological Journal 5(1):72-91 (in Russian)

51. Leberman R, Rabin BR (1959) Metal complexes of histidine. Transactions of the Faraday Society 55:1660-1670. https://doi.org/10.1039/tf9595501660

52. Lehninger AE (1976) Biochemistry, 2nd edn. Worth Publishers Inc, New York

53. Li Y, Yu Z, Song X, Mu Q (2006) Trace metal concentrations in suspended particles, sediments and clams (Ruditapes philippinarum) from Jiaozhou bay of China. Environmental Monitoring and Assessment 121:491-501. https://doi.org/10.1007/s10661-005-9149-6

54. Liang J, Huang X, Yan J, Li Y, Zhao Z, Liu Y, Ye J, Wei Y (2021) A review of the formation of Cr(VI) via Cr(III) oxidation in soils and groundwater. Science of the Total Environment 774:145762. https://doi.org/10.1016/j.scitotenv.2021.145762

55. Lucas J, Vaccaro E, Waite J (2002) A molecular, morphometric and mechanical comparison of the structural elements of byssus from Mytilus edulis and Mytilus galloprovincialis. Journal of Experimental Biology 205(12):1807-1817. https://doi.org/10.1242/jeb.205.12.1807

56. Lutz R, Chalermwat K, Figueras AJ, Gustafson RG, Newell C (1991) Mussel aquaculture in marine and estuarine environments throughout the world. In: Menzel W (ed) Estuarine and Marine Bivalve Mollusk Culture. CRC Press, Boca Raton, pp 57-97

57. Lyngby JE, Brix H (1987) Monitoring of havy metal contamination in the Limfiord, Denmark, using biological indicators and sediment. Science of the Total Environment 64(3):239-252. https://doi.org/10.1016/0048-9697(87)90248-8

58. Manahan SE (2000) Environmental Chemistry. Lewis Publishers, Boca Raton

59. Massa F, Onofri L, Fezzardi D. (2017) Aquaculture in the Mediterranean and the Black Sea: a Blue Growth perspective. In: Nunes PALD, Svensson LE, Markandya A (eds) Handbook on the Economics and Management of Sustainable Oceans. Edward Elgar Publishing, Cheltenham, pp 93-123. https://doi.org/10.4337/9781786430724.00013

60. Mayer DR, Kosmus W, Pogglitsch H, Mayer D, Beyer W (1993) Essential trace elements in humans. Serum arsenic concentrations in hemodialysis patients in comparison to healthy controls. Biological Trace Element Research 37:27-38. https://doi.org/10.1007/bf02789399

61. Mikac N, Kwokal Z, Martincic D, Branica M (1996) Uptake of mercury species by transplanted mussels Mytilus galloprovincialis under estuarine conditions (Krka river estuary). Science of the Total Environment 184:173-182. https://doi.org/10.1016/0048-9697(96)05078-4

62. Ati-Hellal ME, Hellal F (2021) Heavy metals in the environment and health impact. In: Otsuki T (ed) Environmental Health. IntechOpen. https://doi.org/10.5772/intechopen.97204

63. Naik KB. K, Kumar BA, Raju S, Rao GN (2012) Speciation studies of L-histidine complexes of Pb(II), Cd(II), and Hg(II) in DMSO-water mixtures. International Journal of Inorganic Chemistry 3(2):194-205. https://doi.org/10.1155/2012/265249

64. Natale G, Basso N, Ronco A (2000) Effect of $\mathrm{Cr}(\mathrm{VI})$ on early life stages of three species of hylid frogs (Amphibia, Anura) from South America. Environmental Toxicology 15(5):509-512. https://doi.org/10.1002/1522-7278(2000)15:5<509::AID-TOX21>3.0.CO;2-S

65. Nava-Ruiz C, Méndez-Armenta M, Ríos C (2012) Lead neurotoxicity: effects on brain nitric oxide synthase. Journal of Molecular Histology $43: 553-563$. https://doi.org/10.1007/s10735-012-9414-2

66. Neff JM (2002) Bioaccumulation in Marine Organisms. Elsevier, Amsterdam 
67. Nicholson S, Szefer P (2003) Accumulation of metals in the soft tissues, byssus and shell of the mytilid Perna viridis (Bivalvia: Mytilidae) from polluted and uncontaminated locations in Hong Kong coastal waters. Marine Pollution Bulletin 46(8):1039-1043. https://doi.org/10.1016/S0025-326X(03)001528

68. Nolan C, Dahlgaard H (1991) Accumulation of metal radiotracers by Mytilus edulis. Marine Ecology Progress Series 70:165174. https://doi.org/10.3354/meps070165

69. Okoro HK, Fatoki OS, Adekola FA, Ximba BJ, Snyman RG (2012) A review of sequential extraction procedures for heavy metals speciation in soil and sediments. Open Access Scientific Reports 1(3):1-9. https://doi.org/10.4172/scientificreports.181

70. Pospelova NV (2008) Elements of Budget of Carotenoids, a-Tocopherol and Some Metals in the Suspended Matter - Mussels - Bio-deposits System. PhD Thesis, A.O. Kovalevsky Institute of Biology of the Southern Seas, Sevastopol, Ukraine (in Russian).

71. Rainbow PS, Phillips DJH (1993) Cosmopolitan biomonitors of trace metals. Marine Pollution Bulletin 26:593-601. https://doi.org/10.1016/0025326X(93)90497-8

72. Reinecke A, Brezesinski G, Harrington MJ (2017) pH-Responsive self-organization of metal-binding protein motifs from biomolecular junctions in mussel byssus. Advanced Materials Interfaces 4(1):1-11. https://doi.org/10.1002/admi.201600416

73. Rouane-Hacene O, Boutiba Z, Belhaouari B, Guibbolini-Sabatier ME, Francour P, Risso-de-Faverney C (2015) Seasonal assessment of biological indices, bioaccumulation and bioavailability of heavy metals in mussels Mytilus galloprovincialis from Algerian west coast, applied to environmental monitoring. Oceanologia 57:362-374. https://doi.org/1016/j.oceano.2015.07.004

74. Ryabushko LI, Pospelova NV, Balycheva DS, Kovrigina NP, Troshchenko OA, Kapranov SV (2017) Epizoon microalgae of the cultivated mollusk Mytilus galloprovincialis Lam. 1819, phytoplankton, hydrological and hydrochemical characteristics in the mussel-and-oyster farm area (Sevastopol, Black Sea). Marine Biological Journal 2(4):67-83 (in Russian). https://doi:10.21072/mbj.2017.02.4.07

75. Sacchi E, Bergamini M, Lazzari E, Musacchio A, Mor J-R, Pugliaro E (2021) Natural background levels of potentially toxic elements in groundwater from a former asbestos mine in Serpentinite (Balangero, North Italy). Water 13(5):735. https://doi.org/10.3390/w13050735

76. Sakai H, Kojima Y, Saito K (1986) Distribution of heavy metals in water and sieved sediment in the Toyoher River. Water Research 20(5):559-567. https://doi.org/10.1016/0043-1354(86)90019-9

77. SanPiN 42-123-4089-86 (1992) Maximum permissible levels of heavy metals and arsenic in food raw materials and foodstuffs. In: Podolskiy VM (ed) Sanitary Rules and Regulations, Hygiene Standards, and a List of Guidelines and Recommendations for Food Hygiene, Vol 5. Information and Publishing Center of the State Committee for Sanitary and Epidemiological Supervision of the Russian Federation, Moscow, pp 355-357 (in Russian)

78. Schiff KC (2000) Sediment chemistry on the mainland shelf of the southern california bight. Marine Pollution Bulletin 40(3):268270. https://doi.org/10.1016/S0025-326X(99)00216-7

79. Slepchuk KA, Khmara TV, Man'kovskaya EV (2017) Comparative assessment of the trophic level of the Sevastopol and Yuzhnaya bays using E-TRIX index. Physical Oceanography 24(5):60-70. https://doi.org/10.22449/1573-160X-2017-5-60-70

80. Smirnova LL, Andreeva NA, Antonova LS, Misyura AG, Gurik VV, Pichugin VM (2005) Microflora activity as an indicator of the toxicity of sea bottom sediments of the shelf zone of the Black Sea and the Kerch Strait. Ecological Safety of Coastal and Shelf Zones and Integrated Use of Shelf Resources 12:533-539 (in Russian)

81. Smirnova LL, Riabinin Al (2013) Microbiological and elemental composition of aerosols falling on the Crimean coast of the Black Sea. Paleontological Journal 47(10):1198-1204. https://doi.org/10.1134/S0031030113100109

82. Sokolova IM, Evans S, Hughes FM (2004) Cadmium-induced apoptosis in oyster hemocytes involves disturbance of cellular energy balance but no mitochondrial permeability transition. Journal of Experimental Biology 207(19):3369-3380. https://doi.org/10.1242/jeb.01152

83. Stankovic S, Jovic M (2012) Health risks of heavy metals in the mediterranean mussels as seafood. Environmental Chemistry Letters 10:119-130. https://doi.org/10.1007/s10311-011-0343-1

84. Stankovic S, Jovic M, Milanov R, Joksimovic D (2011) Heavy metals concentrations (Zn, Cu, Pb, Cd, As and Hg) in the Mediterranean mussel (Mytilus galloprovincialis) and evaluation of mussel quality and possible human health risk from cultivated and wild sites of the southeastern Adriatic Sea, Montenegro. Journal of the Serbian Chemical Society 76(12):1725-1737. https://doi.org/10.2298/JSC110420095S

85. Suhre MH, Gertz M, Steegborn C, Scheibel T (2014) Structural and functional features of a collagen-binding matrix protein from the mussel byssus. Nature Communications. https://doi.org/10.1038/ncomms4392

86. Sunlu U (2006) Trace metal levels in mussels (Mytilus Galloprovincialis L. 1758) from Turkish Aegean sea coast. Environmental Monitoring and Assessment 114:273-286. https://doi.org/10.1007/s10661-006-4780-4

87. Szefer P, Fowler SW, Ikuta K, Osuna PF, Ali AA, Kim BS, Fernandes HM, Belzunce MJ, Guterstam B, Kunzendorf H, Wo1owicz M, Hummel H, Deslous-Paoli M (2006) A comparative assessment of heavy metal accumulation in soft parts and byssus of mussels from subarctic, temperate, subtropical and tropical marine environments. Environmental Pollution 139(1):70-78. https://doi.org/10.1016/j.envpol.2005.04.031

88. Szefer P, Frelek K, Szefer K, Lee Ch.-B, Kim B.-S, Warzocha J, Zdrojewska I, Ciesielski T (2002) Distribution and relationships of trace metals in soft tissue, byssus and shells of Mytilus edulis trossulus from the southern Baltic. Environmental Pollution 120(2):423-444. https://doi.org/10.1016/S02697491(02)00111-2

89. Szefer P, Ikuta K, Kushiyam S, Szefer K, Frelek K, Geldon J (1997) Distribution and association of trace metals in soft tissue and byssus of Mytilus edulis from the east coast of Kyushu Island, Japan. Archives of Environmental Contamination and Toxicology 32:184-

190. https://doi.org/10.1007/s002449900173

Page 12/15 
90. Szefer, P, Ikuta K, Frelek, K, Zdrojewska I, Nabrzyski M (1999) Mercury and other trace metals (Ag, Cr, Co, and Ni) in soft tissue and byssus of Mytilus edulis from the east coast of Kyushu Island, Japan. The Science of the Total Environment 229(3): 227-234. https://doi.org/10.1016/s0048-9697(99)00079-0

91. Temerdashev ZA, Eletskii II, Kaunova AA, Korpakova IG (2017) Determination of heavy metals in Mytilus galloprovincialis Lamarck mussels using the ICPAES method. Analytics and Control 21(2):116-124 (in Russian). https://doi.org/10.15826/analitika.2017.21.2.009

92. Ünlü MY, Fowler SW (1979) Factors affecting the flux of arsenic through the mussel Mytilus galloprovincialis. Marine Biology 51:209-219. https://doi.org/10.1007/BF00386800

93. USEPA (1989) Risk Assessment Guidance for Superfund (RAGS); United States Environmental Protection Agency: Washington, DC

94. USEPA (2020) Risk Based Concentration Table; United States Environmental Protection Agency, Washington, DC

95. Viarengo A, Canesi L, Pertica M et. al. (1990) Heavy metal effects on lipid peroxidation in the tissues of Mytilus galloprovincialis Lam. Comparative Biochemistry and Physiology 97(1):37-42. https://doi.org/10.1016/0742-8413(90)90168-9

96. Wu X, Gao M, Wang L, Luo Y, Bi R, Li L, Xie L (2014) The arsenic content in marketed seafood and associated health risks for the residents of Shandong, China. Ecotoxicology and Environmental Safety 102:168-173. https://doi.org/10.1016/j.ecoenv.2014.01.028

97. Yamauchi O, Odani A (1996) Stability constants of metal complexes of amino acids with charged side chains - Part I: Positively charged side chains. Pure and Applied Chemistry 68(2):469-496. https://doi.org/10.1351/pac199668020469

98. Yap A, Ismail S, Tan G (2005) Byssus of the green-lipped mussel Perna viridis (Linnaeus) as a biomonitoring material for Zn. Russian Journal of Marine Biology 31(2):102-108 (in Russian). https://doi.org/10.1007/s11179-005-0050-5

99. Yap CK, Ismail A, Tan SG (2003a) Cd and Zn in the straits of Malacca and intertidal sediments of the west coast of Peninsular Malaysia. Marine Pollution Bulletin 46(10):1348-1353. https://doi.org/10.1016/S0025-326X(03)00193-0

100. Yap CK, Ismail A, Tan SG, Omar H (2003b) Can the byssus of greenlipped mussel Perna viridis (Linnaeus) from the west coast of Peninsular Malaysia be a biomonitoring organ for $\mathrm{Cd}, \mathrm{Pb}$ and Zn? Field and laboratory studies. Environment International 29(44):521-528. https://doi.org/10.1016/S01604120(03)00008-4

101. Zhelyazkov G, Yankovska-Stefanova T, Mineva E, Stratev D, Vashin I, Dospatliev L, Valkova E, Popova T (2018) Risk assessment of some heavy metals in mussels (Mytilus galloprovincialis) and veined rapana whelks (Rapana venosa) for human health. Marine Pollution Bulletin 128:197-201.

https://doi.org/10.1016/j.marpolbul.2018.01.024

\section{Figures}

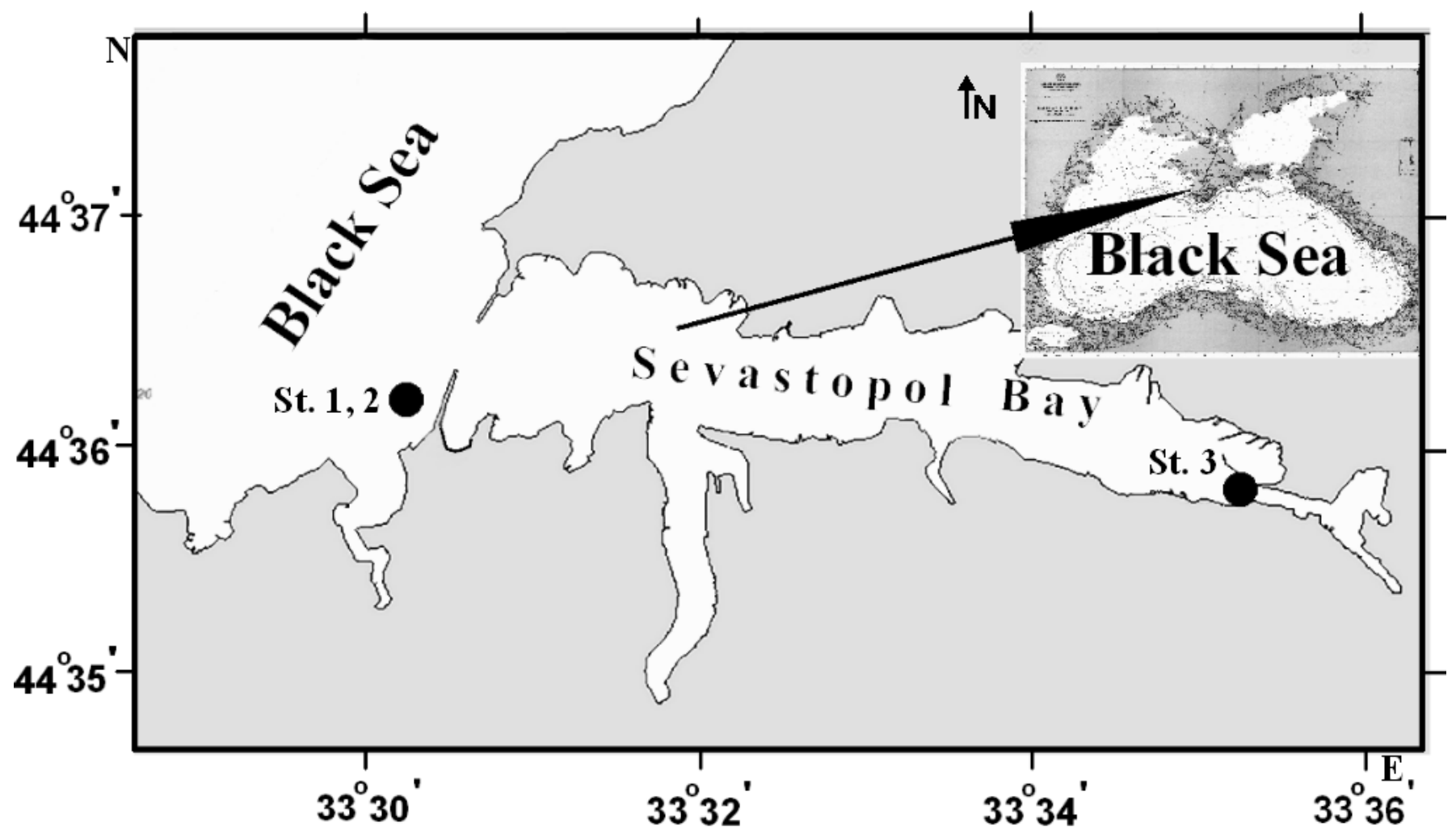

Figure 1

Location of the sampling stations (St. 1-3). 
a

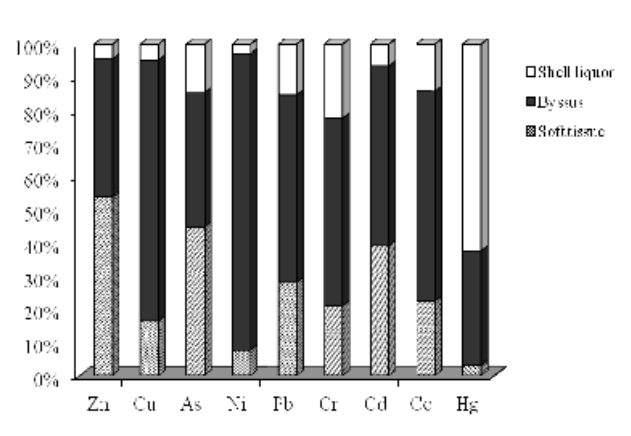

b
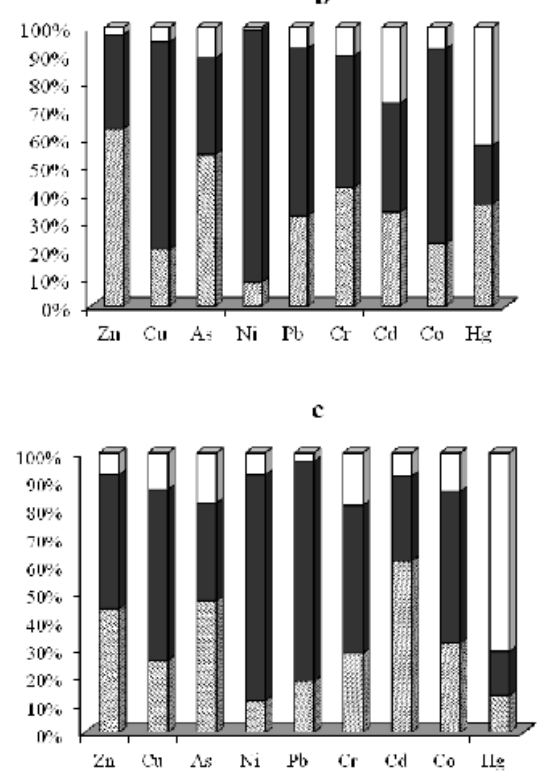

Figure 2

Proportions of the trace element contents in soft tissues, byssus and shell liquor of M. galloprovincialis sampled at (a) Station 1, (b) Station 2, and (c) Station 3

(a)

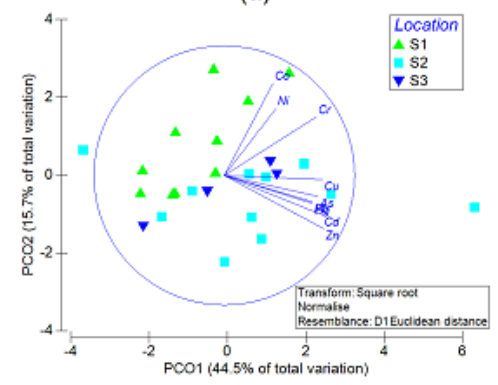

(b)

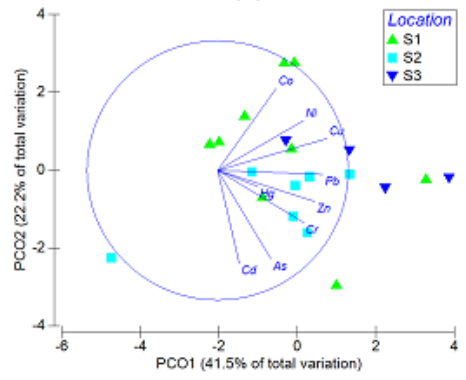

Figure 3

Principal component analysis of trace element contents by location factor in (a) soft tissues and (b) byssus of M. galloprovincialis. S1 = Station $1, \mathrm{~S} 2$ = Station 2, S3 =Station 3. Vectors: projections of the Pearson correlation of variables onto the PCO1 - PCO2 plane. 
(a)

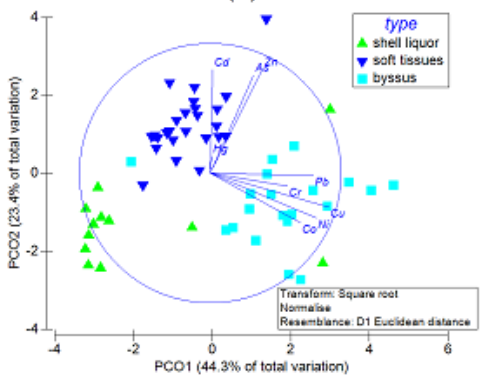

(b)

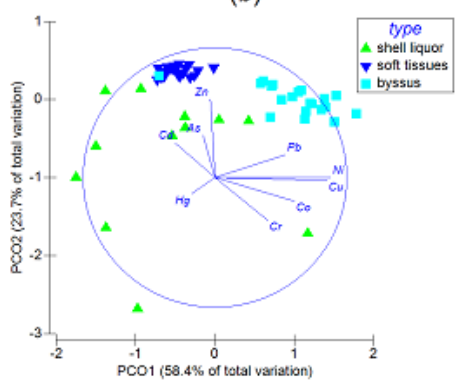

Figure 4

Principal component analysis of trace element contents in mussel body parts with (a) element contents and (b) locations as variables. Vectors: projections of the Pearson correlation of square-root-transformed standardized element contents onto the PCO1 - PCO2 plane.

\section{Supplementary Files}

This is a list of supplementary files associated with this preprint. Click to download.

- SupplementaryMaterial.doc 